Vol 1 No 12020 Juli 2020

Jurnal AlphaEuclidEdu

Received: 08/07/2020; Revised : 29/07/2020; Accepted: 30/07/2020

\title{
EFEKTIVITAS PENDEKATAN PROBLEM POSING PADA MATERI ATURAN SINUS DAN COSINUS DI SMA
}

\author{
${ }^{1 *}$ Saputra, Farly Galuh, ${ }^{2}$ Yusmin, Edy, ${ }^{3}$ Nursangaji, Asep \\ 1,2,3 Pendidikan Matematika FKIP Universitas Tanjungpura Pontianak \\ farlygsaputra@gmail.com
}

\begin{abstract}
Based on the pre research at SMA Taruna Bumi Khatulistiwa there was only 6 of 32 overall students categorized as active in mathematics class and the percentage of the number student who passed the grade in trigonometry was only 59,37\%. The solution for the problem above is try to apply probem posing approach in the class. The aim of this research is to explore the effectivity of problem posing approach in Sines and Cosines Rule at class X SMA Taruna Bumi Khatulistiwa. The research method used in this research is experimental method in the form of pre-experimental design.based on the result of the research learning implementation was categorized as active with the average percentage is $36 \%$ based to the number of students who successfully passed the passing grade. Lastly, student's respons to learning process with the approach is considered positive with the percentage is $92,86 \%$. It can be concleded that learning implementation with problem posing approach in Sines and Cosines Rule at Class X SMA taruna Bumi Khatulistiwa was not effective.
\end{abstract}

Keywords: Effectivity, Problem Posing Approach, Sines Rule and Cosines Rule

\section{Pendahuluan}

Pembelajaran matematika merupakan proses interaksi antara guru dan peserta didik dimana proses tersebut berfungsi sebagai pembentukan pola pikir dan pemahaman suatu definisi maupun hubungan diantara definisi definisi tersebut. Dalam pembelajaran matematika, peserta didik dibiasakan untuk memahami atau menguasai suatu materi matematika didasarkan pada teorema serta definisi. Berdasarkan tujuan pembelajaran matematika yang tercantum dalam Permendikbud No 59 Tahun 2014, tujuan pembelajaran matematika adalah sebagai berikut: (1) memahami konsep matematika, merupakan kompetensi dalam menjelaskan keterkaitan antarkonsep dan menggunakan konsep maupun algoritma, secara luwes, akurat, efisien, dan tepat dalam pemecahan masalah; (2) menggunakan pola sebagai dugaan dalam penyelesaian masalah dan mampu membuat generalisasi berdasarkan fenomena atau data yang ada; (3) menggunakan penalaran pada sifat, melakukan manipulasi matematika baik dalam penyederhanaan, maupun menganalisa komponen yang ada dalam pemecahan masalah dalam konteks matematika maupun di luar matematika; (4) mengkomunikasikan gagasan, penalaran, serta mampu menyusun bukti matematika dengan menggunakan kalimat lengkap, simbol, tabel, diagram, atau media lain untuk memperjelas keadaan atau masalah; (5) memiliki sikap meghargai kegunaan matematika dalam kehidupan, yaitu memiliki rasa ingin tahu, perhatian, dan minat dalam mempelajari matematika, serta sikap ulet dan percaya diri dalam pemecahan masalah; (6) memiliki sikap dan perilaku yang sesuai dengan nilai-nilai dalam matematika dan pembelajarannya, seperti taat azas, konsisten, menjunjung tinggi kesepakatan, toleran, menghargai pendapat orang lain, santun, demokrasi, ulet, tangguh, kreatif, menghargai kesemestaan (konteks, lingkungan), kerjasama, adil, jujur, teliti, cermat, dsb; (7) melakukan kegiatan-kegiatan motorik yang menggunakan pengetahuan matematika; (8) menggunakan alat peraga sedehana maupun hasil teknologi untuk melakukan kegiatan-kegiatan matematika (Kemendikbud, 2014: 328), tentunya diperlukan proses pembelajaran yang baik agar tujuan pembelajaran matematika dapat tercapai. Dalam proses pembelajaran, guru sebaiknya memiliki persiapan yang matang. Persiapan tersebut berupa perencanaan pembelajaran yang meliputi pengelolaan kelas dan penyampaian materi agar dalam proses pembelajaran terjadi hubungan timbal balik antara guru dan peserta didik. Sehingga dalam pembelajaran berlangsung, tidak hanya guru yang aktif dalam menyampaikan materi tetapi peserta didik juga aktif dalam memberikan tanggapan ketika pembelajaran berlangsung. Hal tersebut mengisyaratkan bahwa guru harus merencanakan serta mempersiapkan semua hal yang diperlukan agar proses pembelajaran berjalan dengan lancar dan baik serta membuat siswa aktif dalam pembelajaran. 
Namun, pada kenyataannya aktivitas belajar peserta didik masih terbilang rendah. Aktivitas belajar peserta didik di SMA Taruna Bumi Khatulistiwa dimana selama peneliti mengamati secara langsung di kelas X MIPA 1 pada saat pembelajaran peserta didik enggan untuk bertanya kepada guru walaupun terkadang mereka belum mengerti materi yang diajarkan oleh guru. Dari 31 peserta didik, hanya enam orang peserta didik yang bertanya dan menanggapi terkait materi yang diajarkan oleh guru. Hal itu dikarenakan mereka malu bahkan takut untuk bertanya. Selain masalah aktivitas belajar peserta didik, masalah yang paling sering dikeluhkan adalah ketuntasan hasil belajar peserta didik. Berdasarkan data yang diperoleh mengenai hasil belajar matematika kelas X MIPA 1 pada tahun ajaran 2018/2019 untuk materi trigonometri memiliki rata-rata 55,4 dengan persentase peserta didik yang mencapai kriteria ketuntasan minimum (KKM) yaitu 75 sebesar 40,63\% dan persentase peserta didik yang belum mencapai KKM sebesar 59,37\%.

Berdasarkan pra-riset yang dilakukan peneliti kepada peserta didik, mereka mengatakan bahwa mengalami kesulitan dalam memahami konsep pada materi trigonometri tersebut, karena pada materi trigonometri terlalu banyak rumus yang diterapkan. Beberapa dari peserta didik juga mengatakan bahwa mereka memahami materi tersebut pada saat guru menjelaskan, namun jika diberikan soal mereka akan kesulitan dalam mengerjakannya. Hal tersebut mengindikasi bahwa apa yang telah dipelajari selama proses pembelajaran berlangsung tidak membekas pada peserta didik. Peserta didik juga mengatakan bahwa guru mengajar seperti pada umumnya, yaitu guru memberikan penjelasan terkait materi yang diajarkan lalu memberikan soal untuk latihan.

Berdasarkan hasil pra-riset tersebut, maka perlu diterapkan pembelajaran yang menyebabkan peserta didik aktif dalam proses pembelajaran serta membuat siswa memahami materi yang diajarkan dengan mudah agar ketuntasan hasil belajar peserta didik juga baik. Dengan demikian kesulitan - kesulitan yang dialami peserta didik dapat diminimalisirkan. Namun, pada kenyataannya pembelajaran matematika yang diterapkan dibeberapa sekolah cenderung menerapkan pembelajaran konvensional, dimana guru mendominasi pembicaraan sementara peserta didik hanya duduk, mendengarkan, dan mencatat apa yang disampaikan oleh guru. Hal tersebut disampaikan juga oleh Latip (2018) dalam artikel yang diterbitkan oleh kompasiana mengatakan bahwa guru saat ini masih sering menggunakan metode pembelajaran konvensional dalam berbagai pembelajaran di setiap jenjang pendidikan.

Namun, jika pendidik menerapkan pembelajaran yang efektif, masalah tersebut akan teratasi. Pembelajaran yang efektif akan terjadi jika pengalaman,bahan-bahan, dan hasil yang diharapkan sesuai dengan tingkat kematangan peserta didik serta latar belakang mereka itu sendiri. Pembelajaran yang efektif akan terjadi jika empat indikator pembelajaran efektif terpenuhi. Indikator tersebut antara lain keterlaksanaan pembelajaran, respons peserta didik, aktivitas belajar peserta didik, dan hasil belajar peserta didik.

Adapun alternatif yang ditawarkan adalah pembelajaran dengan menerapkan pendekatan problem posing. Pendekatan problem posing adalah pendekatan pembelajaran yang dalam kegiatan pembelajarannya peserta didik diminta untuk mengajukan masalah atau soal berdasarkan situasi yang diberikan oleh guru. Dengan menerapkan pendekatan tersebut, peserta didik akan berusaha mencari masalah apa yang akan diajukan serta berusaha untuk bisa menyelesaikannya dengan berbagai cara. Dengan demikian tanpa mereka sadari, mereka dilatih untuk selalu aktif dalam proses pembelajaran berlangsung.

Kurikulum 2013 menganjurkan agar pembelajaran berpusat pada peserta didik. Salah satu pendekatan pembelajaran yang berpusat pada peserta didik adalah problem posing. NCTM (dalam Lavy\&Shriki, 2007) menyatakan bahwa pengajuan soal merupakan komponen yang penting dalam pembelajaran dan pengajaran matematika. Sehubungan dengan pengajuan soal (problem posing), menurut (Siswono, 2005: 3) pengajuan soal intinya meminta peserta didik untuk mengajukan atau membuat masalah (soal) baru sebelum, selama atau sesudah menyelesaikan masalah awal yang diberikan.

Penelitian terdahulu yang relevan adalah penelitian yang dilakukan oleh Jabar (2015) dengan judul Penerapan Pendekatan Problem Posing Untuk Meningkatkan Kemampuan Pemecahan Masalah dimana dalam penelitiannya menunjukkan bahwa jumlah siswa yang mencapai kriteria ketuntasan minimum (KKM) dalam pembelajaran dengan pendekatan problem posing sebanyak 30 dari 31 peserta didik di dalam kelas tersebut. Berdasarkan uraian tersebut, peneliti tertarik untuk melakukan penelitian guna mengetahui efektivitas pendekatan pembelajaran problem posing pada materi trigonometri dengan judul "Efektivitas Pendekatan Problem Posing Pada Materi Aturan Sinus dan Aturan Cosinus Kelas X di SMA Taruna Bumi Khatulistiwa.

\section{Metode Penelitian}


Penelitian ini bertujuan untuk mengetahui efektivitas pendekatan problem posing pada materi aturan sinus dan aturan cosinus di Kelas X SMA Taruna Bumi Khatulistiwa. Berdasarkan tujuan tersebut, maka metode yang cocok untuk penelitian ini adalah metode eksperimen. Jenis rancangan eksperimen yang digunakan yaitu praeksperimen (pre-experimental design) dengan jenis bentuk rancangannya adalah studi kasus dengan satu bidikan (one shot case study).

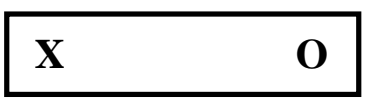

\section{Gambar 1: Rancangan Penelitian}

Subjek dalam penelitian ini adalah siswa kelas X MIPA SMA Taruna Bumi Khatulistiwa yang berjumlah 28 peserta didik. Prosedur yang dilakukan dalam penelitian ini meliputi tiga tahap, yaitu tahap persiapan, tahap pelaksanaan, dan tahap akhir. Langkah-langkah yang akan dilakukan dalam penelitian ini adalah sebagai berikut:

\subsection{Tahap Persiapan}

Langkah-langkah yang dilakukan pada tahapan persiapan yaitu sebagai berikut: (1) melakukan pra-riset di SMA Taruna Bumi Khatulistiwa untuk memperoleh jumlah data Peserta didik kelas X, buku paket yang digunakan dan jumlah jam pelajaran; (2) membuat perangkat pembelajaran berupa RPP dengan pendekatan pembelajaran problem posing; (3) menyusun instrumen penelitian berupa kisi-kisi soal tes, soal tes, kunci jawaban soal tes, pedoman penskoran, angket respon peserta didik, kisi-kisi lembar observasi aktivitas belajar peserta didik, lembar observasi aktivitas belajar peserta didik, dan lembar observasi keterlaksanaan pembelajaran; (4) melakukan validasi perangkat pembelajaran dan instrument penelitian; (5) melakukan revisi perangkat pembelajaran dan instrumen penelitian berdasarkan hasil validasi; (6) mengurus izin penelitian; (7) melakukan uji coba instrumen penelitian; (8) menganalisis data hasil uji coba untuk mengetahui tingkat realibilitas, indeks kesukaran, dan daya pembeda instrumen penelitian. Berdasarkan hasil uji coba, instrumen selanjutnya dapat digunakan sebagai alat pengumpulan data; dan (9) menentukan jadwal penelitian disesuaikan dengan jadwal pelajaran matematika di sekolah tempat penelitian.

\subsection{Tahapan Pelaksanaan}

Langkah-langkah yang dilakukan pada tahapan pelaksanaan adalah sebagai berikut: (1) memberikan perlakuan pada subjek penelitian, yaitu dengan melaksanakan pembelajaran dengan pendekatan problem posing; (2) mengamati dan mengisi lembar observasi aktivitas belajar peserta didik serta keterlaksanaan pembelajaran pada saat kegiatan belajar mengajar berlangsung (observer); (3) memberikan tes untuk hasil belajar peserta didik; (4) memberikan angket untuk mengetahui respons peserta didik; (5) mengolah dan menganalisis data yang diperoleh; dan (6) mendeskripsikan dan membahas hasil pengolahan data, serta menyimpulkan hasilnya.

\subsection{Tahap Akhir}

Langkah-langkah yang dilakukan pada tahapan persiapan yaitu sebagai berikut: (1) penyusunan laporan penelitian; dan (2) penulisan artikel ilmiah.

Teknik pengumpulan data dalam penelitian ini menggunakan teknik pengukuran, teknik observasi, dan teknik komunikasi tidak langsung. Adapun untuk alat pengumpulan datanya meliputi lembar observasi keterlaksanaan pembelajaran, lembar observasi aktivitas belajar siswa, lembar tes hasil belajar, dan lembar angket respon siswa.

\section{Hasil dan Pembahasan}

Hasil penelitian dan pembahasan ini berdasarkan data yang telah diperoleh dari kegiatan penelitian yang dilaksanakan selama dua kali pertemuan di kelas X MIPA 1 SMA Taruna Bumi Khatulisitwa. Penelitian ini dilaksanakan pada tanggal 26 Agustus 2019 dan 28 Agustus 2019. Data yang diperoleh meliputi data hasil 
Vol 1 No 12020 Juli 2020

Jurnal AlphaEuclidEdu

observasi keterlaksanaan pembelajaran, data hasil observasi aktivitas belajar peserta didik, data hasil belajar peserta didik, dan data hasil angket respon peserta didik menggunakan pendekatan problem posing pada materi aturan sinus dan aturan cosinus.

\section{Hasil}

\subsection{Hasil Observasi Keterlaksanaan Pembelajaran}

Naskah manuskrip harus dikirimkan melalui salah satu cara berikut ini (cara yang kedua lebih diutamakan): Pada penelitian ini, keterlaksanaan pembelajaran dilaksanakan dan diamati selama kegiatan belajar mengajar berlangsung yang dilakukan sebanyak dua kali pertemuan. Setiap pertemuan dalam pembelajaran tersebut dilakukan pengamatan keterlaksanaan pembelajaran yang dilakukan oleh guru matematika SMA Taruna Bumi Khatulistiwa, yaitu Bpaka Mulyadi, S.Pd. Berikut hasil pengamatan keterlaksanaan pembelajaran.

Tabel 1

Hasil Observasi Keterlaksanaan Pembelajaran

\begin{tabular}{llllll}
\hline No & $\begin{array}{l}\text { Jenis } \\
\text { Kegiatan }\end{array}$ & $\begin{array}{l}\text { Pertemuan } \\
\mathbf{1}\end{array}$ & $\begin{array}{l}\text { Pertemuan } \\
\mathbf{2}\end{array}$ & $\begin{array}{l}\text { Total } \\
\text { Keseluruhan }\end{array}$ & $\begin{array}{l}\text { Nilai } \\
\text { Maksimum } \\
\text { Tiap } \\
\text { Kegiatan }\end{array}$ \\
\hline $\mathbf{1}$ & Pendahuluan & 20 & 22 & 42 & 48 \\
\hline $\mathbf{2}$ & Inti & 48 & 53 & 101 & 112 \\
\hline $\mathbf{3}$ & Penutup & 13 & 14 & 27 & 32 \\
\hline & Total & 73 & 82 & 170 & 192 \\
\hline & Rata-rata & 3,38 & 3,58 & 3,48 & \\
\hline & Kategori & Baik & Baik & Baik
\end{tabular}

Pengamatan terhadap keterlaksanaan pembelajaran ini dilakukan untuk melihat apakah tahapan dalam pembelajaran menggunakan pendekatan problem posing pada materi aturan sinus dan aturan cosinus terlaksana sesuai dengan tahapan yang ada. Adapun aspek yang diamati dalam lembar observasi keterlaksanaan pembelajaran dalam penelitian ini berjumlah 24 aspek dimana tiap aspek memiliki skor maksimum 4 . Berdasarkan hasil perhitungan persentase keterlaksanaan pembelajaran pada kegiatan pendahuluan, kegiatan inti, dan penutup adalah $90,62 \%, 90,18 \%$, dan $84,38 \%$. Secara keseluruhan rata-rata keterlaksanaan pembelajaran yang didapat dari dua kali pertemuan adalah 3,48. Dengan demikian dapat disimpulkan bahwa keterlaksanaan pembelajaran dengan menggunakan pendekatan problem posing pada materi aturan sinus dan aturan cosinus dalam penelitian berada pada kategori baik.

\subsection{Hasil Observasi Aktivitas Belajar Peserta Didik}

Pada penelitian ini, aktivitas belajar peserta didik selama pembelajaran menggunakan pendekatan problem posing berlangsung diamati oleh tiga orang observer yang merupakan mahasiswa pendidikan matematika sesuai dengan aspek yang diamati dalam lembar observasi aktivitas belajar peserta didik. Pengamatan aktivitas belajar peserta didik dilakukan sebanyak dua kali. Pada pertemuan pertama dan kedua, ketiga observer mengamati peserta didik masing-masing sebanyak sembilan orang. Dengan demikian, pada pertemuan pertama dan kedua terdapat 27 dari 28 peserta didik yang mengikuti pembelajaran. Untuk pertemuan pertama dan pertemuan kedua terdapat peserta didik yang tidak mengikuti pembelajaran dikarenakan sakit, namun dengan peserta didik yang berbeda. Aspek aktivitas belajar peserta didik pada lembar observasi disesuaikan dengan tahapan pembelajaran pendekatan problem posing. Berdasarkan hasil pengamatan aktivitas belajar peserta didik menggunakan pendekatan problem posing pada pertemuan pertama dan pertemuan kedua diperoleh hasil sebagai berikut: (1) pada kegiatan pendahuluan pada pertemuan pertama diperoleh hasil sebesar $71,60 \%$ dan pertemuan kedua sebesar $72,84 \%$. Artinya, aktivitas belajar peserta didik pada kegiatan pendahuluan mengalami peningkatan sebesar 1,24\%; (2) pada kegiatan inti diperoleh hasil sebesar 79,01\% dan pertemuan kedua sebesar 78,19\%; (3) pada kegiatan penutup diperoleh hasil sebesar $75,93 \%$ untuk pertemuan pertama dan pertemuan kedua. Berdasarkan hasil pengamatan aktivitas belajar peserta didik pada dua pertemuan diperoleh rata-rata persentase aktivitas belajar peserta didik sebesar 75,58\%. Dengan demikian, dapat disimpulkan bahwa aktivitas belajar 
Vol 1 No 12020 Juli 2020

Jurnal AlphaEuclidEdu

peserta didik dalam pembelajaran dengan menggunakan pendekatan problem posing termasuk dalam kategori aktif.

\subsection{Hasil Belajar Peserta Didik}

Tes hasil belajar dalam penelitian ini diberikan kepada peserta didik setelah peserta didik selesai menerima pembelajaran dengan menggunakan pendekatan problem posing pada materi aturan sinus dan aturan cosinus yang dilakukan sebanyak dua kali pertemuan. Soal tersebut diberikan untuk mengukur pemahaman peserta didik pada materi aturan sinus dan aturan cosinus yang telah dipelajari. Jumlah peserta didik yang mengikuti tes sebanyak 28 orang. Hasil belajar peserta didik dapat diketahui melalui skor yang mereka peroleh pada lembar jawaban. Skor yang mereka dapat telah disesuaikan dengan pedoman penskoran yang ada. Skor tersebut dijumlahkan lalu dikonversikan menjadi nilai. Dengan demikian, dapat diketahui nilai peserta didik yang tuntas dan tidak tuntas. Peserta didik dikatakan tuntas apabila mereka memperoeh nilai minimal 75. Setelah diketahui jumlah peserta didik yang tuntas dan tidak tuntas, selanjutnya jumlah tersebut dipersentasekan untuk mengetahui ketuntasan klasikal.

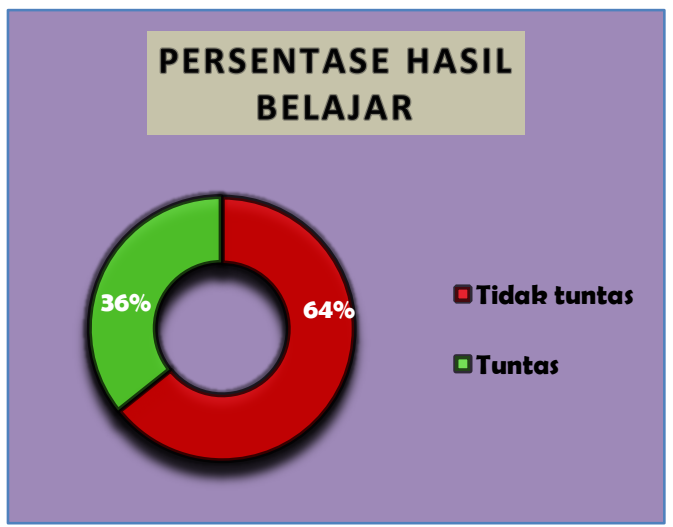

\section{Gambar 2: Persentase Ketuntasan Tes Hasil Belajar}

Berdasarkan diagram tersebut, persentase peserta didik yang tuntas dalam menjawab soal tes adalah $36 \%$ dan kurang dari $85 \%$ maka dapat disimpulkan bahwa ketuntasan hasil belajar peserta didik secara klasikal tidak terpenuhi

\subsection{Angket Respons Peserta Didik}

Pengambilan data angket respons peserta didik pada penelitian ini diberikan kepada 28 responden. Responden dalam penelitian adalah peserta didik kelas X MIPA 1 SMA Taruna Bumi Khatulistiwa yang telah memperoleh pembelajaran dengan menggunakan pendekatan problem posing pada materi aturan sinus dan aturan cosinus. Penyebaran angket ini bertujuan untuk mengetahui respons peserta didik terhadap pembelajaran dengan pendekatan problem posing. Berdasarkan perhitungan angket yang diperoleh, persentase peserta didik yang memberikan respons positif adalah $71,43 \%$, dan persentase peserta didik yang memberikan respons sangat positif adalah 21,43\%. Dengan demikian jumlah peserta didik yang memberikan respons positif dan sangat positif adalah 92,86\%. Dapat disimpulkan bahwa repons peserta didik terhadap pembelajaran dengan menggunakan pendekatan problem posing adalah positif.

\section{Pembahasan}

\subsection{Keterlaksanaan Pembelajaran}

Berdasarkan hasil observasi keterlaksanaan pembelajaran selama dua kali pertemuan diperoleh hasil, yaitu pada hasil observasi keterlaksanaan pembelajaran pertemuan kedua lebih tinggi dibandingkan dengan pertemuan 
pertama. Hal ini dikarenakan pada pertemuan pertama baik peneliti maupun peserta didik masih berusaha untuk menyesuaikan diri agar suasana kegiatan belajar mengajar tidak kaku dan canggung karena pembelajaran yang diterapkan sedikit berbeda dari biasanya serta terdapat beberapa peserta didik yang mengantuk karena SMA Taruna Bumi Khatulistiwa merupakan sekolah asrama dimana kegiatan peserta didik cukup padat baik pada jam belajar maupun setelah belajar. Untuk mengurangi rasa kantuk peserta didik, peneliti membuat guyonan serta menghampiri dan mengingatkan peserta didik yang mengantuk untuk tetap fokus. Pada pertemuan kedua, kegiatan belajar mengajar sudah menjadi lebih cair, baik peneliti maupun peserta didik. Peserta didik telah mengetahui tahapan dari pembelajaran yang diterapkan sehingga dalam menginstruksikan peserta didik tidak membutuhkan waktu yang lama. Hasil perolehan nilai rata-rata keterlaksanaan pembelajaran menggunakan pendekatan problem posing yang dilakukan peneliti adalah 3,48. Artinya, keterlaksanaan pembelajaran dengan menggunakan pendekatan pendekatan problem posing pada materi aturan sinus dan aturan cosinus berada pada kategori baik.

\subsection{Aktivitas Belajar Peserta Didik}

Berdasarkan hasil observasi aktivitas belajar peserta didik selama dua kali pertemuan diperoleh hasil, yaitu (1) pada kegiatan pendahulaun terjadi peningkatan aktivitas belajar peserta didik pada pertemuan kedua dikarenakan peneliti tidak langsung memulai kegiatan belajar dan mengajar, namun mengajak peserta didik untuk berdialog dan bercerita tentang kejadian apa yang sudah dialami pada hari itu serta peserta didik juga bertanya kepada peneliti terkait penelitian yang peneliti ambil. Hal tersebut, sejalan dengan apa yang diungkapkan Bistari (2018: 25) ada tiga faktor yang mempengaruhi aktivitas belajar, yaitu faktor stimulasi belajar, metode belajar, dan individual. Dalam hal ini, mengajak peserta didik untuk berdialog dan bercerita adalah stimulasi belajar yaitu, segala hal di luar individu yang merangsang individu untuk mengadakan reaksi atau perbuatan belajar. Wujud yang menyebabkan adanya dorongan atau motivasi individu seperti daya tarik media, ganjaran, gaya mengajar guru, lingkungan sekitar, dan fasilitas pembelajaran; (2) pada kegiatan inti, terjadi penurunan persentase aktivitas belajar peserta didik pada pertemuan kedua sebesar 0,82\%. Hal ini dikarenakan dalam kegiatan inti terjadi penurunan pada saat berdiskusi, jumlah peserta didik yang bertanya kepada guru (peneliti) tidak sebanyak seperti pertemuan pertama. Pada kegiatan inti terdapat dua tahapan yaitu accepting post solution dan challenging post solution. Accepting post soltion memuat kegiatan membaca LKPD, bertanya kepada guru terkait hal-hal yang belum dipahami, melakukan diskusi dengan teman sekelompok dalam memahami contoh yang ada di LKPD. Challenging post solution memuat kegiatan menyelesaikan masalah yang ada di LKPD dan mengajukan serta menyelesaikan masalah yang mereka buat. Namun, dalam tahapan mengajukan masalah, terdapat beberapa masalah ang diajukan oleh peserta didik tidak sesuai dengan situasi yangdiberikan oleh guru (peneliti); (3) Pada kegiatan penutup, tidak terjadi peningkatan dan penurunan pada kedua pertemuan tersebut. Dengan kata lain, persentase untuk kedua pertemuan pada kegiatan penutup adalah sama.

\subsection{Hasil Belajar Peserta Didik}

Berdasarkan hasil perhitungan nilai tes hasil belajar, diperoleh jumlah peserta didik yang tuntas hasil belajarnya adalah 10 peserta didik dengan persentase sebesar 36\% dan jumlah peserta didik yang belum tuntas hasil belajarnya adalah 18 peserta didik dengan persentase sebesar 64\%. Jika dilihat dari jawaban yang mereka tuliskan pada lembar jawaban, maka terdapat beberapa alasan yang menyebabkan mengapa mereka belum mencapai nilai kriteria minimum. Mereka belum paham terkait materi yang dipelajari dan salah dalam menggunakan konsep perhitungan serta salah menerapkan rumus. Selain dari temuan pada jawaban peserta didik dalam mengerjakan soal yang diberikan, guru mata pelajaran mengatakan bahwa salah satu penyebab banyaknya peserta didik yang belum mencapai nilai kriteria ketuntasan minimum adalah kemampuan peserta didik dalam operasi hitung, hal ini diungkapkan oleh guru yang mengajar karena pada saat awal tes masuk ajaran baru, mayoritas dari mereka salah dalam mengerjakan soal yang diberikan guru mata pelajaran. Hal ini sejalan dengan pernyataan Bistari (2018: 103) ada dua faktor yang mempengaruhi hasil belajar, yaitu faktor internal dan eksternal. Faktor internal meliputi faktor jasmaniah, psikologis, dan kelelahan. Dalam hal ini, pernyataan yang diungkapkan oleh guru matematika di kelas X SMA Taruna Bumi Khatulistiwa termasuk dalam faktor psikologis, yang terbagi lagi menjadi intelegensi, perhatian, minat, bakat, motif, kematangan, dan kesiapan. Artinya faktor yang menyebabkan hasil belajar peserta didik rendah tergolong adalah faktor intelegensi yaitu menggunakan konsep-konsep yang abstrak secara efektif. Selain kemampuan peserta didik 
dalam menjawab soal yang diberikan dan faktor internal yang telah dipaparkan, terdapat faktor lain yang menyebabkan ketuntasan hasil belajar tergolong sangat rendah. Faktor tersebut berasal dari soal yang diberikan oleh peneliti, hal yang belum diajarkan oleh guru / dipelajari oleh peserta didik. Menurut hemat peneliti, hal itulah yang menyebabkan banyak peserta didik yang tidak dapat menjawab soal nomor tiga sehingga ketuntasan hasil belajar peserta didik secara klasikal tidak mencapai kategori baik $(85 \%)$.

\subsection{Respons Peserta Didik}

Dari angket tersebut, diperoleh respons peserta didik terhadap pembelajaran dengan pendekatan problem posing pada materi aturan sinus dan aturan cosinus sebanyak 6 peserta didik $(21,43 \%)$ memberikan respons sangat positif, 20 peserta didik $(71,43 \%)$ memberikan respons positif, dan 2 peserta didik $(7,14 \%)$ memberikan respons negatif. Dengan demikian, dapat disimpulkan bahwa rata-rata peserta didik memberikan respons positif terhadap pembelajaran dengan pendekatan problem posing pada materiaturan sinus dan aturan cosinus.

\subsection{Efektivitas Pembelajaran Menggunakan Pendekatan Problem Posing}

Efektivitas pembelajaran menggunakan pendekatan problem posing pada penelitian ini ditinjau dari empat indikator, yaitu sebagai berikut: (1) keterlaksanaan pembelajaran berada pada kategori "Baik" atau "Sangat Baik" dengan rata-rata keterlaksanaan pembelajaran berada pada rentang 3,00 - 4,00; (2) aktivitas belajar peserta didik berada pada kategori "Aktif" atau "Sangat Aktif" dengan rentang interval 61\% - 100\%; (3) hasil belajar peserta didik mencapai ketuntasan klasikal dengan ketentuan lebih dari atau sama dengan $85 \%$ peserta didik mecapai nilai kriteria minimum; (4) respons peserta didik yaitu "Positif" atau "Sangat Positif". Berdasarkan hasil penelitian dan analisis dari keempat indikator efektivitas pembelajaran dengan pendekatan problem posing hanya tiga indikator yang memenuhi syarat, yaitu keterlaksanaan pembelajaran, aktivitas belajar peserta didik, dan respons peserta didik. Sedangkan untuk hasil belajar peserta didik belum memenuhi kriteria "Baik" atau "Sangat Baik" karena ketuntasan hasil belajar peserta didik hanya mencapai 36\% saja.

\section{Kesimpulan}

Berdasarkan hasil penelitian dan pembahasan yang dipaparkan sebelumnya, dapat disimpulkan bahwa pembelajaran menggunakan pendekatan problem posing pada materi aturan sinus dan aturan cosinus di kelas $\mathrm{X}$ SMA Taruna Bumi Khatulistiwa tidak efektif, hal tersebut dikarenakan hanya tiga indikator saja yang terpenuhi. Adapun hasil dari tiap indikator efektivitas adalah sebagai berikut: (1) keterlaksanaan pembelajaran menggunakan pendekatan problem posing pada materi aturan sinus dan aturan cosinus di kelas X SMA Taruna Bumi Khatulistiwa tergolong baik $(3,48)$; (2) aktivitas belajar peserta didik dalam pembelajaran menggunakan pendekatan problem posing pada materi aturan sinus dan aturan cosinus di kelas X SMA Taruna Bumi Khatulistiwa tergolong aktif (75,58\%); (3) hasil belajar peserta didik setelah mengikuti pembelajaran menggunakan pendekatan problem posing pada materi aturan sinus dan aturan cosinus di kelas X SMA Taruna Bumi Khatulistiwa belum mencapai ketuntasan belajar secara klasikal (36\%); (4) respons peserta didik terhadap pembelajaran menggunakan pendekatan problem posing pada materi aturan sinus dan aturan cosinus di kelas $\mathrm{X}$ SMA Taruna Bumi Khatulistiwa adalah positif $(92,86 \%)$.

\section{Referensi}

Bistari. 2018. Mewujudkan Penelitian Tindakan Kelas. Pontianak: PT. Ekadaya Multi Inovasi.

Jabar, Abdul. 2015. Penerapan Pendekatan Problem PosingUntuk Meningkatkan Kemampuan Pemecahan Masalah. Banjarmasin: STKIP PGRI Banjarmasin.

Kemendikbud. 2014. Peraturan Menteri Pendidikan dan Kebudayaan Republik Indonesia Nomor 59 Tahun 2014 Tentang Kurikulum 2013 Sekolah Menengah Atas/ Madrasah Aliyah [Online]. https://suaidinmath.files.wordpress.com/2014/09/lampiran-i-permen-nomor-59-th-2014_b.doc. diakses tanggal 6 Februari 2019

Latip, Abdul. 2018. Saatnya Tinggalkan Metode Pembelajaran Konvensional [Online]. https://www.kompasiana.com/altip/5c0db2cbab12ae71c8361e04/saatnya-tinggalkan-metodepembelajaran-konvensional?page=all. diakses tanggal 19 Juni 2019 
Vol 1 No 12020 Juli 2020

Jurnal AlphaEuclidEdu

Lavy and Shriki. 2007. Problem Posing As A Means For Develoving Mathematical Knowledge Of Prospective Teacher [Online]. Australian Journal Of Teacher Education 3: 129 - 136. http://googlescholar.com/ diakses tanggal 19 Desember 2018

Siswono, Tatag Yuli Eko. 2005. Upaya Meningkatkan Kemampuan Berpikir Kreatif Peserta didik Melalui Pengajuan Masalah [Online]. http://tatagyes.files.wordpress.com/2009/11/paper05/problemposing.pdf. diakses tanggal 15 Oktober 2018. 